\title{
サウンドスケープの視点からみた住区における 居住環境のアメニティと地区らしさ
}

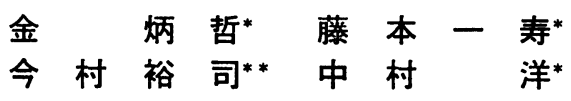

Amenity of Residential Environment and Regional Identity in Residential Area from the View-Point of Soundscape

\begin{abstract}
摘要 : 本研究は, 住民に対するアンケート調査の結果から, 住区における居住環境のアメニティと地区らしさの形成 に関与する環境要素に関して, サウンドスケープの視点から検討したものである。調查対象地としては, 福岡市内の $9 つ の$ 近隣住区を取り上げた。調查・検討の結果, 住民は, 住宅周辺の公園緑地, 殊に小鳥の鳴き声などが聞こえる ような真の自然にアメニティを感じており，地区らしさの形成に関与する環境要素は，由緒ある神社やお寺などの伝 統的・文化的環境要因によって構成されていることが分かった。
\end{abstract}

はじめに

近年, 生活水準の向上に伴って人々の関心や欲求の対 象が物的充足から精神的満足へと变容しつつあり, 居住 環境においても環境の “質”が求められるようになって きている。環境の “質”を論ずるなかで “アメニティ (Amenity)”という言葉がよく用いられ，またその重 要性が指摘されている。

ところで，“アメニティ”という言葉が日本で頻繁に 使われるようになったのは，1976年にOECD（経済協 力開発機構 ${ }^{11}$ が「日本の環境政策」というレポートの 中で「日本は数多くの公害防除の戦闘を勝ちとったが, 環境の質を高めるための戦争ではまだ勝利をおさめてい ない・・・日本の環境政策の課題は “アメニティ”にあ る」と報告したことからである。以来, “アメニティ” という言葉は, 環境の “質”を議論する際の重要なキー ワードとして用いられてきたが，その定義は必ずしも定 まってはいない。居住環境の “質” の議論の中で用いら れる場合は，一般に「人間にとって快適で好ましいと感 じられる環境及び住み心地のよさ」²),「人々に（結果的

に）快適さや満足さを感じてもらおうとして（意図をもっ て）整備されたもの」3)，「快適で美しい雾囲気のある環 境」)といった意味で用いられている。そこで，本論文
であ上記の意味を総括的に捉え，「人間にとって快適で あると感じさせる環境」という意味で, “アメニティ” という言葉を用いることにし，以下に居住環境の “質” について論を展開することにする。

前述のように, 居住環境の “質”を求める声か高くなっ てきているが, 居住環境を具体的にどのように整備すれ ば環境の質的向上，すなわちアメニティ向上につながる かということに関する計画的手法は確立されていない。 快適な居住環境を創造するためには，まず住民がどのよ うな環境要因にアメニティを感じているのかを明らかに する必要があると考える。

藤本 $(1991)^{5)}$ は，住民の「居住環境に対する満足度」 には，家の広さや間取り，日当りなどの「住宅性能」だ けではなく, 住宅周辺の「音環境」も大きく関係してい ると報告している。これは, 住宅周辺の音環境が居住環 境のアメニティのために重要な環境要因の一っとなって いることを意味するものと考えられる。また，最近“サ ウンドスケープ”という新しい概念を基に, 音を配慮し た公園・緑地の環境改善に関する研究6-12) の動きも見ら れる。サウンドスケープとは, 不必要な音や邪魔になる 音を排除（従来の騒音対策）するだけでなく，地域や場 に必要な音を積極的に活用（演出）することも含んだ総

*九州大学工学部建築学科 **清水建設(侏) 
合的な音環境計画を目指す概念であって, 例えば, 特定 の音を, その音が含まれる音環境と切り離して個別に扱 わないで, その他の様々な音や場との関係, さらには地 域の人々との関係なども考慮しながら，音環境をトータ ルに捉えようとする概念 ${ }^{13.14)}$ である。

このような背景を踏まえて, 本研究は, サウンドスケー プという視点に基づいて, 音を配虑した居住環境整備の あり方に関する計画的示唆を得ることを究極的な目的と し，その第一段階の研究として，近隣住区における居住 環境のアメニティと地区らしさの形成に関与する環境要 素について検討したものである。具体的には, 以下の 5 つの項目について検討を行っだ。

・居住環境改善に対する住民の欲求

・住民が住区に抱いている四象

・居住環境のアメニティ形成に関与する環境要因

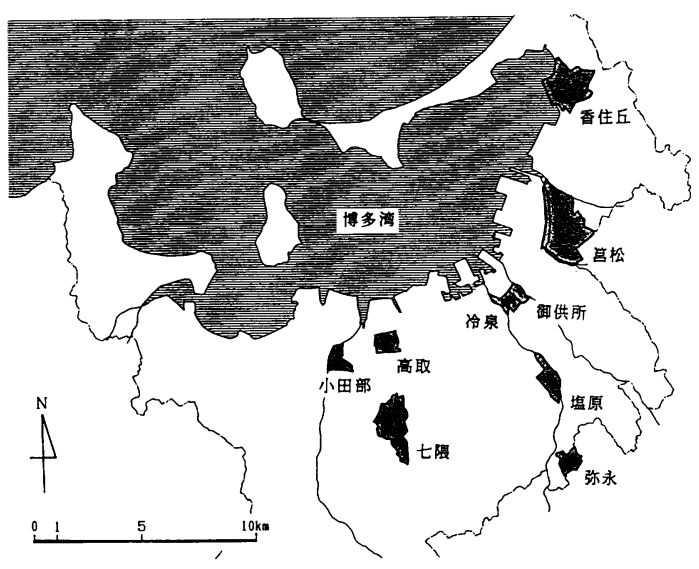

図-1 調査対象住区の位置

表-1 調查対象住区の特徽

\begin{tabular}{|c|c|c|}
\hline 住 区 & 用途地域 & 特 \\
\hline 香住丘 & 住居地域 & $\begin{array}{l}\text { 福岡市果部の高台に位置し、稚木林の緑や博多湾の眺望なと、自 } \\
\text { 然境境に富んだ閑静な住宅地である。 }\end{array}$ \\
\hline 管 松 & 击工業地域 & 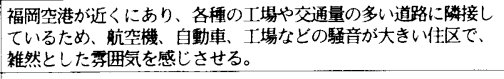 \\
\hline 御供所 & $\begin{array}{l}\text { 商業地域 } \\
\text { 住居地域 }\end{array}$ & 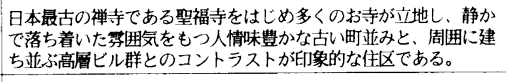 \\
\hline 冷 泉 & 商業地域 & 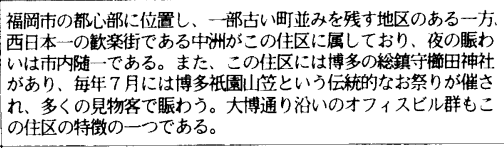 \\
\hline 塩 原 & 住居地域 & 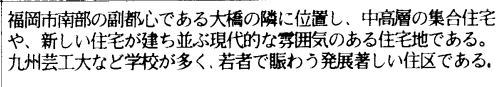 \\
\hline 弥 永 & 住居地域 & $\begin{array}{l}\text { 福岡市の南の端に位罾する住宅地域で、今なお田畑や用水路が多 } \\
\text { く残っている䦨静な区住区である }\end{array}$ \\
\hline 七 隈 & 住居地域 & 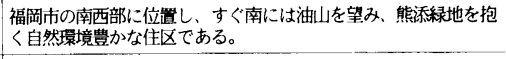 \\
\hline 高 取 & 住居地域 & 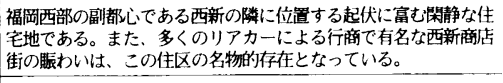 \\
\hline 小田部 & 住居地域 & 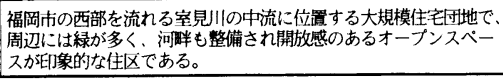 \\
\hline
\end{tabular}

・居住環境のアメニティ形成に関与する公園・緑地の 環境要素

・地区らしさの形成に関与する音とフィジカルな環境 要素

調查対象地としては, 福岡市内の 9 つの近隣住区 (図一 1 ）を取り上げ，各住区ごとに住区内の住区基幹公園 （児童公園または近隣公園）を $2 つ$ 選定した。ただし， “御供所”之“冷泉”だけは, 1 つの住区基幹公園之, 緑地空間 ( “御供所”では, 聖福寺その他のお寺の境内 を中心とする緑地，“冷泉”では，櫛田神社の境内を中 心とする緑地）を各々選定した。表－1に各住区の特徴 を示す。そして，各公園周辺の住民に対して，公園・緑 地を含む居住環境全般に関するアンケート調査を実施し た。

\section{1. アンケート調查の概要}

アンケート票は, 表一 2 に示すように, 住まいの周辺 環境や日常生活の中で触れ合える公園・緑地環境, 音環 境などに関する質問で構成した。

調査対象住戸は, 先に選定した各住区の公園または緑 地から一定範囲内にある住戸のうちから任意に選んだ。 今回の調査では, 範囲として近隣公園の誘致圈 (500m) を用いた。そして，調査対象住戸宛てにアンケート票を 郵送し，アンケート票の回答を依頼した。配布の数日後, 各回答者の家を訪問し，アンケート票を回収した。調査 は1991年 6 月に実施した。

アンケート票の配布数は 1,118 票で, 回収数は745票 （回収率は67\%）であった。図ー2に回答者の属性を示

\section{表ー 2 アンケート票の内容}
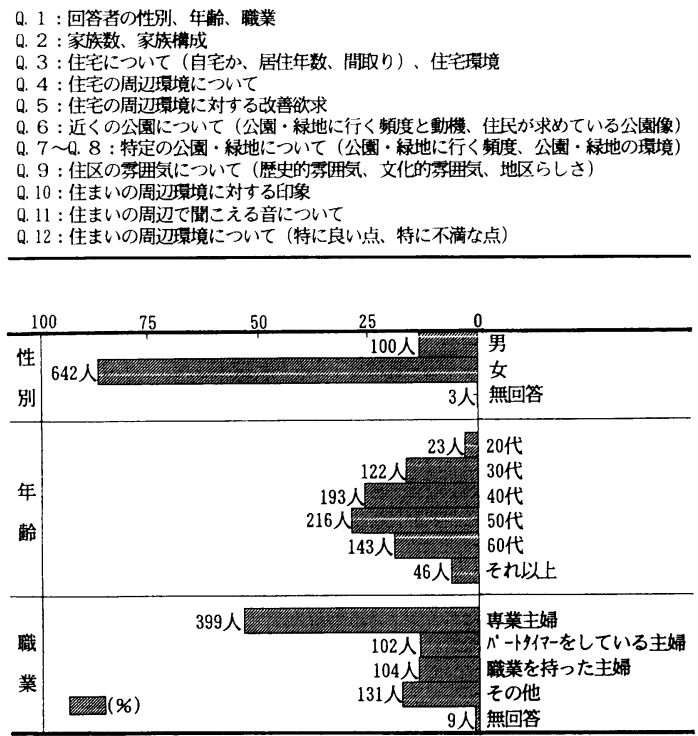

図-2 回答者の属性

造園雑誌 56 (2)，1992 
す。回答者の $87 \%$ 女゙女性（81\%が主婦）であった。これ は, 自宅にいる時間が比較的長い主婦の回答を期待した 調査者の意図に沿う結果である。

\section{2. 居住環境改善に対する住民の欲求}

アンケート調査結果の最初の分析として,「周辺の環 境に対する改善欲求」（Q.5）の回答結果について検討 する。質問に掲げた18項目のうち指摘率の高い13項目 ${ }^{15)}$ を図ー 3 に示す。図より「交通安全対策の強化」（指摘 率45\%),「防犯対策の強化」(43\%),「自然環境の保全」 (42\%)，「自動車による公害の防止」(39\%) などの項目 に対する指摘率の高いことが分かる。

これらの項目は，“道路交通の問題”之“自然環境の 保全・整備の問題” の 2 点にまとめられる。第 1 の問題 に関しては，福岡市における道路交通網の整備が他の大 都市に比べて非常に遅れていることを鑑みると, 当然の 結果であると考えられるが, 一方, 第 2 点の “自然環境 の保全・整備”に対する高い指摘率は注目すべきことで ある。すなわち,これは, 住民が居住環境の改善にとっ て“自然環境の保全・整備”が重要であると強く認識し ていることを示すむので, 居住環境のアメニティの形成 に自然環境の要因が大きく関与していることを示唆して いると考えられる。

\section{3. 住民が住区に抱いている印象}

次に「住まいの周辺環境に対する印象」（Q.10）の回 答結果を分析する。

Q.10は，住民が住宅の周辺環境に対してどのような 印象を抱いているかを探る目的で設けた質問である。質 問は, それぞれ 7 段階の尺度を持つ24個の形容詞対で構 成されるSD法評定である。なお 24 個の形容詞対は，藤 本らのこれまでの研究 ${ }^{16)}$ 参考にして決定した。

得られた評定値を因子分析（主因子法・バリマックス 回転）した結果, 表一 3 に示すように 3 個の共通因子が 抽出された。

第 1 因子は，“澄んだ”“すっきりした”“静かな” “緑の多い”“広々とした”“清潔な”“快い”などの 形容詞に代表される因子で,「快適性」を表す因子と解 釈できる。同様に, “現代的な” “力強い”“派手な” などの形容詞に代表される第 2 因子は「現代性」を表す 因子、“親しみのある”“親しみやすい”“明るい”な どの形容詞に代表される第 3 因子は「親密性」を表す因 子, と解釈される。

各住区の因子得点を図ー 4 に示す。この図を観察する 之, 住民の抱く住区への印象（「快適性」「現代性」「親 密性」）という観点から，各住区の特徴が理解できる。

“香住ヶ丘”と“小田部”は,「快適性」因子の得点 の高いのが特徵的である。表ー 1 に示したように, “香

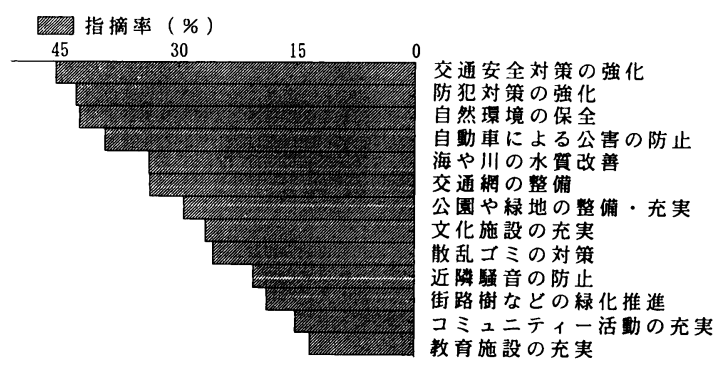

図ー3 今後の居住環境の改善に対する住民の欲求

表一 3 因子負荷量

\begin{tabular}{|c|c|c|c|}
\hline 変 量 & 第1因子 & 第2因子 & 第3因子 \\
\hline $\begin{array}{l}\text { 澄んだ } \\
\text { すっきりした } \\
\text { 静かな } \\
\text { 緑の多い } \\
\text { 広々とした } \\
\text { 清潔な } \\
\text { 快い } \\
\text { 自然的な } \\
\text { きれいな } \\
\text { 豊かな }\end{array}$ & $\begin{array}{l}0.714 \\
0.670 \\
0.595 \\
0.553 \\
0.552 \\
0.533 \\
0.508 \\
0.485 \\
0.471 \\
0.401\end{array}$ & $\begin{array}{r}0.114 \\
0.223 \\
-0.200 \\
-0.021 \\
0.291 \\
0.155 \\
0.156 \\
-0.237 \\
0.191 \\
0.382\end{array}$ & $\begin{array}{r}0.226 \\
-0.013 \\
0.173 \\
0.037 \\
0.115 \\
0.213 \\
0.221 \\
0.099 \\
0.041 \\
0.289\end{array}$ \\
\hline $\begin{array}{l}\text { 現代的な } \\
\text { 力強い } \\
\text { 派手な } \\
\text { 活気のある } \\
\text { 大きい } \\
\text { 軽やかな }\end{array}$ & $\begin{array}{r}-0.127 \\
0.114 \\
-0.077 \\
0.062 \\
0.248 \\
0.269\end{array}$ & $\begin{array}{l}0.531 \\
0.488 \\
0.475 \\
0.469 \\
0.454 \\
0.448\end{array}$ & $\begin{array}{r}-0.077 \\
0.281 \\
-0.003 \\
0.050 \\
0.285 \\
0.143\end{array}$ \\
\hline $\begin{array}{l}\text { 親しみのある } \\
\text { 親しみやすい } \\
\text { 明るい } \\
\text { 解放的な }\end{array}$ & $\begin{array}{l}0.156 \\
0.142 \\
0.356 \\
0.172\end{array}$ & $\begin{array}{r}-0.003 \\
0.090 \\
0.405 \\
0.429\end{array}$ & $\begin{array}{l}0.861 \\
0.570 \\
0.468 \\
0.435\end{array}$ \\
\hline
\end{tabular}

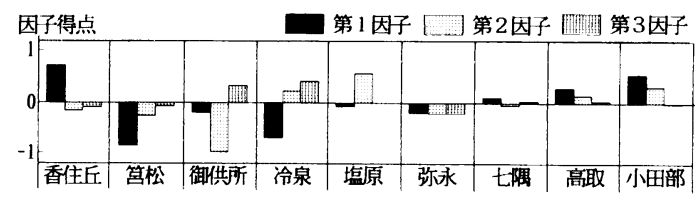

図-4 各調査対象住区の因子得点

住ヶ丘”は博多湾に, “小田部” は室見川にそれぞれ面 しており，両住区とも他の住区に比べて自然環境に恵ま れていることが，「快適性」因子の得点の高さにつながっ たのではないかと予想される。

これらの住区とは対照的に，「快適性」因子の得点が 低いのが “笘松”である。この住区には, 工場や倉庫が 多く, また航空機騒音も大きいが, そのようなことが 「快適性」因子の得点の低さとなって表れたのではない 
かと予想される。

“御供所”は,「現代性」因子の得点が低く,「親密性」 因子の得点が高いという興味深い特徴を示す。ここには, 日本最古の禅寺である聖福寺をはじめ多くのお寺が立地 しており，いまだに下町の風情が残っているが，こうし たことが“現代的ではないが親しみのある”住区との評 価になったのではないかと予想される。

“冷泉”は,「快適性」因子の得点が低く,「親密性」 因子の得点の高いのが特徴的である。ここは，自然環境 の乏しい都心部に位置しているものの, 福岡の代表的な 祭りである “博多祇園山笠”で有名な櫛田神社が立地し ており，“地元意識”の強い住区である。「親密性」の 高さは, こうしたことに起因するものと理解される。

“塩原”は「現代性」因子の得点の高いことが特徽的 である。ここは, 福岡市の副都心として発展著しい“大 橋”に隣接し，住宅や中高層のマンションが次々に建設 されており，また文教地区として若者の多い住区でもあ る。これらが “現代的”との評価につながったのではな いかと予想される。

“弥永”“七隈” “高取”は, 3つの因子得点の何れ もが小さく, 特に顕著な特徴の見られない住区である。

以上のように，住民の「周辺環境の印象」に関する SD法評定結果を因子分析して得られた各住区の特徴は, 著者らが主観的に感じている各住区の印象とほぼ一致し ており, 図-4は妥当な結果であると判断できる。

\section{4.アメニティと居住環境要因の関係}

そこで，因子分析で抽出された「快適性」因子がどの ような環境要因と関連しているかについて検討する。

アンケート票のQ.3とQ.4において, 各々「住宅の 環境 (10項目)」と「住宅の周辺環境 (15項目)」に関す る質問（すべて 5 段階の両極尺度）を設けたが，この結 果を表一 4 に示す 6 個の環境要因にまとめる。このとき 各要因は，当該質問項目の評定値の平均値とし，さらに “良い”“普通”“悪い”の 3 カテゴリーに変換した。

このようにして求められた 6 個の環境要因と因子分析 で得た第 1 因子（快適性）との関連性を検討するため, 因子得点を外的基準，各環境要因を説明変数として数量 化 I 類分析を行なった。結果を表一 5 に示す。

分析結果の重相関係数は0.605であり, 一応信頼でき る結果であるといえる。そこで結果をみると， 6 個の環 境要因の中で「自然環境」の要因が偏相関係数・カテゴ リースコアのレンジともに一番大きい $(0.36,0.80) こ$ とが分かる。すなわち,「快適性」は「自然環境」の良 否と高い相関が認められた。このような結果は, 居住環 境のアメニティにとって自然環境の存在が最も大切であ ると住民に（潜在的に）意識されていることを示すむの と解釈される。

\section{表－4 居住環境要因に関する質問項目}

\begin{tabular}{|c|c|}
\hline 環境要因 & 質＼cjkstart問＼cjkstart項 \\
\hline 住宅性能 & $\begin{array}{l}\text { Q.3 1)広さ, 2)間取り，3）日当り，4)明るさ, 5)風通し } \\
\text { 6)眺望, 9)プライバシー, 10)建物の外観 }\end{array}$ \\
\hline 音環境 & \begin{tabular}{|lll} 
Q. 3 & 7)駩音, 8)振動 \\
Q. 4 2)騒音, 3)振動
\end{tabular} \\
\hline 衛 生 & $\begin{array}{l}\text { Q.4 1)空気のきれいさ, 4)悪臭, 5)下水道 } \\
\text { 6)ゴミ・し尿の処理状況 }\end{array}$ \\
\hline 自然㻴境 & Q.4 9)公園・遊び場，10)緑の豊かさ \\
\hline 交通の便 & Q.4 12)買物の便，13)通勤·通学の便 \\
\hline $\begin{array}{l}\text { 施設・ } \\
\text { 社会璄境 }\end{array}$ & $\begin{array}{l}\text { Q.4 7)教育・文化施設, 8)医療・福祉施設, } \\
\text { 11) スポーツ施設, 14)近所の付き合いのしやすさ } \\
\text { 15)事故・犯罪等からの安全 }\end{array}$ \\
\hline
\end{tabular}

表一 5 第 1 因子の因子得点と居住環境要因の関係

\begin{tabular}{|c|c|c|c|c|}
\hline 環境要因 & カテゴリー & デー夕数 & $\begin{array}{c:c}\text { カテコリーー } & \text { スンジ } \\
\text { スコア }\end{array}$ & $\begin{array}{l}\text { 偏相関 } \\
\text { 係 数 }\end{array}$ \\
\hline 自然環境 & $\begin{array}{l}\text { 良 } \\
\text { 普 通 } \\
\text { 悪 }\end{array}$ & $\begin{array}{lll}2 & 5 & 5 \\
1 & 67 \\
1 & 17 \\
\end{array}$ & $\begin{array}{rr:l}0.29 & \\
-0 . & 08 & 0.80 \\
-0.51 & 50 \\
\end{array}$ & 0.36 \\
\hline 音環境 & $\begin{array}{l}\text { 良 } \\
\text { 普 通 } \\
\text { 悪 }\end{array}$ & $\begin{array}{lll}1 & 8 & 8 \\
1 & 4 & 9 \\
2 & 0 & 2\end{array}$ & 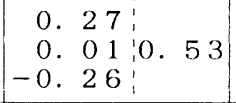 & 0.26 \\
\hline 衛 生 & $\begin{array}{l}\text { 良 } \\
\text { 普 通 } \\
\text { 悪 }\end{array}$ & $\begin{array}{r}312 \\
185 \\
42\end{array}$ & 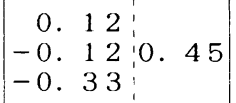 & 0.16 \\
\hline 交通の便 & $\begin{array}{ll}\text { 良 } & \text { } \\
\text { 普 } & \text { 通 } \\
\text { 悪 }\end{array}$ & $\begin{array}{rll}3 & 80 \\
1 & 11 \\
4 & 8\end{array}$ & 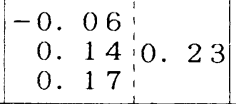 & 0.13 \\
\hline $\begin{array}{l}\text { 施設· } \\
\text { 社会環境 }\end{array}$ & $\begin{array}{l}\text { 良 } \\
\text { 普 通 } \\
\text { 悪 }\end{array}$ & $\begin{array}{rl}2 & 25 \\
243 \\
71\end{array}$ & $\begin{array}{rll:ll}-0 . & 0 & 1 & & \\
0 . & 0 & 6 & 0 . & 23 \\
-0 . & 1 & 7 & & \end{array}$ & 0.10 \\
\hline 住宅性能 & $\begin{array}{l}\text { 良 } \\
\text { 普 通 } \\
\text { 悪 }\end{array}$ & $\begin{array}{lll}2 & 5 & 6 \\
1 & 8 & 0 \\
1 & 0 & 3\end{array}$ & $\begin{array}{rrr:rrr}0 . & 0 & 6 & & & \\
-0 . & 0 & 6 & 0 . & 1 & 2 \\
-0 . & 0 & 4 & & & \end{array}$ & 0.08 \\
\hline
\end{tabular}

これは，2.の結果と符合するもので，自然環境の保 全・整備が居住環境のアメニティを向上させる上で重要 であることを示唆するもので, 大変興味深い。

\section{5. アメニティと公園・緑地の環境要素の関係}

近隣住区において，住民の日常生活の中で自然環境と 触れ合える場は，一般には児童公園や近隣公園などの住 区基幹公園と神社やお寺などの緑地空間であると考えら れる。そこで次に, 居住環境のアメニティが住区におけ る公園・緑地のどのような環境要素と関係し，またどの 程度関係しているかについて検討する。

アンケート票のQ.7とQ.8において，「住区内に立 地する公園・緑地」についての質問を設けている。これ らは, 公園や緑地の様々な環境に関する19項目の質問 （すべて 5 段階の両極尺度）から構成されているが，こ れを前節と同様の方法で, 表一 6 に示す 7 個の環境要素 
にまとめ,これらと第 1 因子の因子得点との関係を数量 化 I 類分析した。結果を表一 7 に示す。

分析結果の重相関係数は 0.382 であり, 先の分析結果 よりもやや信頼性は低下したが， 7 個の環境要素の中で は「自然音（小鳥のさえずりや虫の鳴き声など）」が最 あ「快適性」之相関が高い（偏相関係数 : 0.41 , カテコ リースコアのレンシ：0.17）という興味深い結果が得ら れた。

このような結果は, 住民が周刃の環境に対してアメニ ティを感じる度合が, 公園・緑地の自然の豊かさ (小鳥 のさえずりや虫の鳴き声などの聞こえるほど）之樑く係 わっていることを示すすので, 居住環境のアメニティを

\section{表ー6 公園・緑地環境要素に関する質問項目}

\begin{tabular}{|c|c|}
\hline 環境要素 & 質＼cjkstart問＼cjkstart項 \\
\hline 規 模 & 2)広さ，5)遊ひ場，11)運動スペース \\
\hline 距 離 & 1)公園・緑地までの距離 \\
\hline 緑・景色 & $\begin{array}{l}\text { 8)緑の豊かさ，9)季節を感じさせる木や花，14)花壇 } \\
\text { 15)芝，17)景色 }\end{array}$ \\
\hline $\begin{array}{l}\text { 衛生・ } \\
\text { 維持管理 }\end{array}$ & $\begin{array}{l}\text { 3)犬のフンやコミなど, 4) 維持管理, 7)風通し } \\
\text { 20)日当り }\end{array}$ \\
\hline 騒 音 & 13)騒音 \\
\hline 自然の音 & 19)小鳥のさえずりや虫の鳴き声 \\
\hline 施 設 & $\begin{array}{l}\text { 6)ベンチなどの休䚋施設, 10)案内や標識, } \\
\text { 12)夜間の安全施設, 18)夜間の照明 }\end{array}$ \\
\hline
\end{tabular}

\section{表- 7 第 1 因子の因子得点と公園・粶地環境要素の関係}

\begin{tabular}{|c|c|c|c|c|}
\hline 環境要素 & カテゴリー & デー夕数 & \begin{tabular}{|c:c} 
カテゴリー & レンジ \\
スコア &
\end{tabular} & $\begin{array}{l}\text { 偏相関 } \\
\text { 係 数 }\end{array}$ \\
\hline 自然音 & $\begin{array}{l}\text { 良 } \\
\text { 普 通 } \\
\text { 悪 } \\
\end{array}$ & $\begin{array}{lll}1 & 0 & 4 \\
1 & 3 & 0 \\
1 & 6 & 1\end{array}$ & 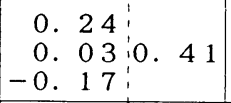 & 0. 17 \\
\hline $\begin{array}{l}\text { 衛生・・ } \\
\text { 維持管理 }\end{array}$ & $\begin{array}{l}\text { 良 } \\
\text { 普 通 } \\
\text { 悪 }\end{array}$ & $\begin{array}{r}141 \\
167 \\
87 \\
\end{array}$ & 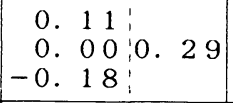 & 0. 11 \\
\hline 規 模 & $\begin{array}{l}\text { 良 } \\
\text { 普 通 } \\
\text { 悪 }\end{array}$ & $\begin{array}{lll}1 & 0 & 1 \\
1 & 3 & 0 \\
1 & 6 & 4\end{array}$ & 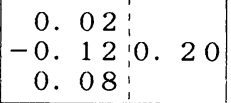 & 0.10 \\
\hline 緑·景色 & $\begin{array}{l}\text { 良 } \\
\text { 普 通 } \\
\text { 悪 } \\
\end{array}$ & $\begin{array}{r}79 \\
153 \\
163\end{array}$ & $\begin{array}{rr:rrr}0 . & 1 & 5 & & \\
0 . & 0 & 1 & 0 . & 23 \\
-0 . & 0 & 8 & & \\
\end{array}$ & 0.08 \\
\hline 距 離 & $\begin{array}{ll}\text { 良 } & \text { } \\
\text { 普 } & \text { 通 } \\
\text { 悪 }\end{array}$ & $\begin{array}{r}310 \\
63 \\
22\end{array}$ & 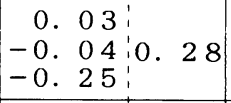 & 0.08 \\
\hline 施 設 & $\begin{array}{l}\text { 良 } \\
\text { 普 通 } \\
\text { 悪 }\end{array}$ & $\begin{array}{rl} & 26 \\
132 & 32 \\
237\end{array}$ & 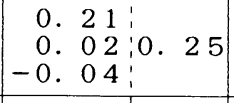 & 0.07 \\
\hline 音 & $\begin{array}{l}\text { 良 } \\
\text { 普 通 } \\
\text { 悪 }\end{array}$ & $\begin{array}{lll}1 & 1 & 8 \\
1 & 7 & 6 \\
1 & 0 & 1\end{array}$ & 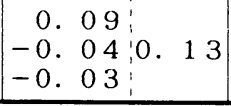 & 0.08 \\
\hline
\end{tabular}

向上させるためには, 自然環境の保全・整備が大切であ ることが, 改めて認識された。

\section{6. 地区らしさの形成に関与する音とフィジカルな環境 要素}

杉本 $(1988)^{2)}$ は, “アメニティの創出はただアメニ ティを高めるということでディスアメニティの要素を除 去し，アメニティを高める環境要素を守り育み，それを 住民の協力で実行するだけでは一面的なアメニティの創 出しか期待できない" と語っているが，筆者らも，居住 環境が快適であるためには，アメニティ形成に関与する 環境要素が豊かであると同時に，それぞれの環境が固有 の “らしさ”を備えていることも重要であると考える。 そこで次に, 調查住区の “地区らしさ”に焦点をあてて, 音とフィジカルな環境要素との関連について検討し, 地 区らしさの形成に音がどのように関与しているかを明ら かにする。

アンケート票のQ.9において,「住区の自然・建物・ 施設・催物について, “歴史的雾囲気”や“文化的雾囲 気”や“地区らしさ”を感じるもの」に関して自由回答 を求めた。結果を表一 8 に示す。自由記入のために指摘 率は小さいが, 各住区の特徴がよく据えられている。

またQ.11では，「日常生活で聞く様々な音」に関する 質問を行った。この質問では，筆者らのこれまでの研究 16.17)を参考にして48種類の音の名前を提示し，各々につ いて，“地区の環境をよくしていると思うか”“地区ら しさを感じるか”“悩まされているか”を回答させた。

これらの質問の回答から，住民が住区に対して“地区 らしい”と感じている「音」と「フィジカルな環境要素」 が得られると期待される。これらの結果が，3.で得ら れた住区の特徵（「快適性」「現代性」「親密性」）とどの ように関連するかについて検討を試みる。

3.で抽出された因子ごとに“地区らしさ”を比較・ 検討するために，9つの住区のうち，各因子の因子得点 の高い住区と低い住区に特に着目し，そのような住区ご とに“地区らしい”と指摘された「音」を整理してみた。 結果を表ー 9 に示す。この表には，指摘率が10\%以上で かっ指摘率の違いが 4 倍以上のものだけを示している。

まず第 1 因子「快適性」に着目する。因子得点の高い

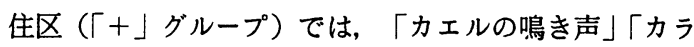
スの鳴き声」などが “地区らしさを感じる音”として指 摘されている。これらの音は，“環境を良くしている音” として受け止められている。表-8から分かるように， 環境要素む“和白千潟”や “室見川”などの自然環境と 関連するものが “地区らしい”要素としてあげられてい

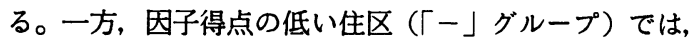
自然環境に関連する要素はほとんど指摘されていない。 「航空機の音」が “地区らしい音”としてあげられてい 
表ー8＼cjkstart地区らしさを感じる環境要素

\begin{tabular}{|c|c|c|c|c|c|c|c|c|c|c|c|c|c|c|c|c|c|c|}
\hline & & & & & & & & & & & & & & & & & \multicolumn{2}{|c|}{ 単位：指摛重 (\%) } \\
\hline 区 & 番 住 & & 管 & & 供 & & 冷 & & 盐 & & 弥 & & $t$ & & 高 & 取 & 小田茢 & 部 \\
\hline $\begin{array}{l}\text { 地区らしさを } \\
\text { 感しる棵填要素 }\end{array}$ & 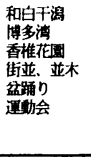 & $\begin{array}{r}22.6 \\
11.3 \\
9.4 \\
7.5 \\
1.9 \\
1.9\end{array}$ & 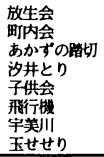 & $\begin{array}{l}5.3 \\
3.9 \\
3.9 \\
2.6 \\
2.6 \\
2.6 \\
2.6 \\
2.6 \\
\end{array}$ & 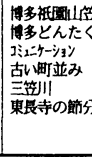 & $\begin{array}{r}16.3 \\
10.2 \\
4.1 \\
4.1 \\
4.1 \\
4.1\end{array}$ & 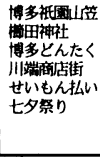 & $\begin{array}{l}35.0 \\
20.0 \\
20.0 \\
15.0 \\
10.0 \\
10.0\end{array}$ & 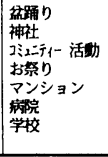 & $\begin{array}{l}7.1 \\
7.1 \\
7.1 \\
4.3 \\
2.9 \\
2.9 \\
2.9\end{array}$ & 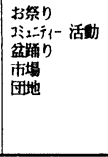 & $\begin{array}{l}8.5 \\
8.5 \\
3.4 \\
3.4 \\
1.7\end{array}$ & 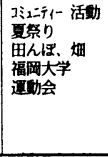 & $\begin{array}{l}8.8 \\
5.9 \\
4.4 \\
4.4 \\
2.9\end{array}$ & 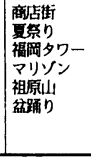 & $\begin{array}{r}19.4 \\
7.5 \\
4.5 \\
4.5 \\
4.5 \\
3.0\end{array}$ & 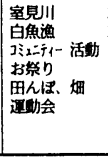 & $\begin{array}{r}16.3 \\
10.9 \\
5.4 \\
3.3 \\
3.3 \\
3.3\end{array}$ \\
\hline
\end{tabular}

表-9 因子得点ट音の指摘率からみた住区の特徴

\begin{tabular}{|c|c|c|c|c|c|c|c|c|c|c|c|c|c|c|c|c|c|c|}
\hline \multirow{2}{*}{$\begin{array}{l}\text { 因子得点 } \\
\text { 吅た } \\
\text { 住区の特徵 }\end{array}$} & \multicolumn{6}{|c|}{ 地区らしさを感じる音 } & \multicolumn{6}{|c|}{ 地区の環境を良くしていると思う音 } & \multicolumn{6}{|c|}{ 悩まされている音 } \\
\hline & \multicolumn{2}{|c|}{ 第1因子 } & \multicolumn{2}{|c|}{ 第2因子 } & \multicolumn{2}{|c|}{ 第3因子 } & \multicolumn{2}{|c|}{ 第1因子 } & \multicolumn{2}{|c|}{ 第2因子 } & \multicolumn{2}{|c|}{ 第3因子 } & \multicolumn{2}{|c|}{ 第1因子 } & \multicolumn{2}{|c|}{ 第2因子 } & \multicolumn{2}{|c|}{ 第3因子 } \\
\hline & + & - & + & - & + & - & + & - & + & - & + & - & + & - & + & - & + & - \\
\hline 音の種類 & $\begin{array}{l}\text { 香 } \\
\text { 住 } \\
\text { 丘 } \\
\text { 小 } \\
\text { 田 } \\
\text { 部 }\end{array}$ & $\begin{array}{l}\text { 管 } \\
\text { 松 } \\
\text { 冷 } \\
\text { 泉 }\end{array}$ & $\begin{array}{l}\text { 塩 } \\
\text { 原 }\end{array}$ & $\begin{array}{l}\text { 御 } \\
\text { 供 } \\
\text { 所 }\end{array}$ & $\begin{array}{l}\text { 御 } \\
\text { 供 } \\
\text { 所 } \\
\text { 冷 } \\
\text { 泉 }\end{array}$ & 弥 & $\begin{array}{l}\text { 香 } \\
\text { 住 } \\
\text { 兵 } \\
\text { 小 } \\
\text { 田 } \\
\text { 部 }\end{array}$ & $\begin{array}{l}\text { 松 } \\
\text { 泠 } \\
\text { 泉 }\end{array}$ & $\begin{array}{l}\text { 塩 } \\
\text { 原 }\end{array}$ & $\begin{array}{l}\text { 御 } \\
\text { 供 } \\
\text { 所 }\end{array}$ & $\begin{array}{l}\text { 御 } \\
\text { 供 } \\
\text { 所 } \\
\text { 冷 } \\
\text { 泉 }\end{array}$ & 弥 & $\begin{array}{l}\text { 香 } \\
\text { 集 } \\
\text { 少 } \\
\text { 田 } \\
\text { 部 }\end{array}$ & $\begin{array}{l}\text { 笘 } \\
\text { 松 } \\
\text { 泠 } \\
\text { 泉 }\end{array}$ & 塩 & $\begin{array}{l}\text { 御 } \\
\text { 供 } \\
\text { 所 }\end{array}$ & $\begin{array}{l}\text { 御 } \\
\text { 供 } \\
\text { 所 } \\
\text { 泠 } \\
\text { 泉 }\end{array}$ & 弥 \\
\hline & 4.1 & 26.0 & 17.1 & 16.3 & 18.8 & 6.8 & 0.7 & 1.0 & 0.0 & 0.0 & 0.0 & 0.0 & 6.9 & 59.4 & 30.0 & 24.5 & 24.6 & 42.4 \\
\hline & & 6.3 & 10.0 & 2.0 & $\begin{array}{r}7.2 \\
\end{array}$ & & 2.1 & 0.0 & 0. & 2.0 & 1.4 & 1.7 & 5.5 & $\begin{array}{r}4.2 \\
\text { 4. }\end{array}$ & 5.7 & 0.0 & 0.0 & 3 \\
\hline & 8 & 11.5 & 5.7 & 22.4 & 26.1 & 13. & 0.0 & 4.2 & 2.9 & 6.1 & 10.1 & 3.4 & 0.0 & 2.1 & 0.0 & 0.0 & 2.9 & 0. \\
\hline 虫の鳴き声 & 17.9 & 4. 2 & 2.8 & 2.0 & $\begin{array}{r}2.9 \\
\end{array}$ & 15. 3 & 44.8 & 16.7 & 21.4 & 22.4 & 15.9 & 22.0 & 0.7 & 0.0 & 1.4 & 0.0 & 0.0 & 0.0 \\
\hline カエルの鳴き声 & 23.4 & 5.2 & 0.0 & 0.0 & 0.0 & 18.6 & 12.4 & 8.3 & 1.4 & 0.0 & 0.0 & 20.3 & 1.4 & 2.1 & 0.0 & 2.0 & 1.4 & 10.2 \\
\hline & 13.8 & 2. 1 & 8.6 & 12.2 & 11.6 & 6.8 & 4.8 & 1.0 & 1.4 & 6.1 & 5.8 & 1.7 & 5. 5 & 13.5 & 5.7 & 10.2 & 10.1 & 10. \\
\hline & 1.4 & 4.2 & 2.9 & 30.6 & 27.5 & & 1.4 & 2.1 & 7.1 & 36.7 & 29.0 & 5.1 & 0.0 & 0.0 & 0.0 & 0.0 & 0.0 & 0. \\
\hline 神社の太鼓の音 & 0.0 & 11.5 & 0.0 & 8. 2 & 15.9 & 0.0 & 0.0 & 3.1 & 1.4 & 6.1 & 5.8 & 0.0 & 0.0 & 1.0 & 0.0 & 4. 1 & 4. 3 & 0.0 \\
\hline
\end{tabular}

注) ' + ' : 因子得点が+0.3以上の住区, ‘-' : 因子得点が-0.3以下の住区

第 3 因子の因子得点がー3以下の住区はなかったが、比較検討のために第 3 因子の因子得点が最も低かった弥永を揭載する。

るが,これは“悩まされている音”となっている。

このような結果は, “地区らしい音や環境要素”のう

ち，自然環境に係わりのあるものがアメニティの向上に とって重要であることを示しており，4.や5.の結果と あ符合している。

次に第 2 因子「現代性」に着目する。「十」グループ には指摘率の高い音は見られないが，これは，現代性の 雾囲気の形成に「音」はあまり関与していないことを示 すむのと解釈できる。逆に「一」グループ（「現代性」 に対する意味での「伝統性」の高い地区といってもいい であろう)では, 地区らしい音として「お寺の鐘の音」 や「お祭りの音」の指摘率が高く, また地区らしさを感 じる環境要素としても“博多祇園山笠”や“博多どんた く”などの祭りやお寺に関連したものがあげられている。 また第 3 因子「親密性」においても，「十」グループで は，「お寺の鐘の音」「お祭りの音」などが地区らしさを 感じる音, そして「祭り」「神社」「お寺」が地区らしさ を感じる環境要素としてあげられている。

このようなことから，祭りやお寺などに関連する“伝 統的”で “親しみのある”環境要素や音が, “地区らし さ”と深く係わっていると推察できる。したがっで地 区らしさ”を育むためには,「祭り」に代表されるよう
な地区の伝統・文化を継承・育成し，それを支える「神 社」「お寺」などの緑地空間を保全・整備することが重 要であると考えられる。

\section{おわりに}

住民に対するアンケート調查の結果から，住区におけ る居住環境のアメニティと地区らしさの形成に関与する 環境要素について, サウンドスケープという視点から検 討した。その結果, 住民は, 住宅周辺の公園・緑地空間, 殊に小鳥のさえずりや虫の鳴き声などが聞こえるような 真の自然にアメニティを感じており, 地区らしさの形成 に関与する環境要素は, 主に由緒ある神社やお寺などの ような伝統的・文化的環境要因によって構成されている ことが認識できた。したがって, 快適で個性のある居住 環境を創造するためには, 住民が日常的に触れ合うこと のできる児童公園や近隣公園などの住区基幹公園やお寺・ 神社などの緑地空間を保全・整備することが重要である と考える。

ところで，今回の調査対象である児童公園や近隣公園 は，そもそも児童や近隣に居住する者の利用に供するこ とを目的とした小規模な公園であるので，これらの公園 だけを対象にして住区の居住環境向上に必要な豊かな自 
然を確保・整備することは, 現実的にはなかなか難しい と思われる。むしろ，これらの公園を核とした住区全体 の緑空間を整備してゆく必要があろう。また, 神社やお 寺などの緑地空間に関しても，これまでは歴史的文化的 に重要な建造物だけが保全・整備の対象とされ, 周辺一 体を含めて神社やお寺の空間にふさわしい環境となるよ うに配慮しようとする視点が欠落している場合が多かっ たのではないかと酳念される。本調查研究の結果から, 神社やお寺などの緑地空間は, 居住環境のアメニティや 地区らしさを形成する重要な環境要素を支える役割を担っ ていることが示されたが, このような点を踏まえて, 今 後は，緑地空間を含む住区全体の居住環境づくりを目指 す必要があろう。これに関するより詳しい検討は今後の 課題である。

\section{謝 辞}

本研究の一部は, 財団法人日本住宅綕合センター平成 2 年度調查研究助成金によるものである。ここに記して 深謝致します。最後に，本調查研究を手伝ってくれた九 州大学建築学科の桑原誠至君之安留友湖君 - 福岡大学建 築学科の山浦昇二君に感謝します。

\section{参考文献・補注}

1）木原啓吉，伊東考 (1989）：「環境」イミダス1989, 841-852

2 ) 杉本正美 (1988) : 都市アメニティ創出のための基 本的な考え方,（財)九州環境管理協会会報「環境管 理」第17号, 27-30

3 ) 進士五十八 (1987) : 緑のまちづくり学, 学芸出版 社, 62-67

4 ) 前田勇 (1985)：アメニティにおける人間的要因, （社）日本観光協会「月刊観光」No.222, 7-12

5 ) K.Fujimoto (1991): Relation between Evaluation of Residential Environment and Annoyance of Noise, Korea-Japan Joint Symp. on Acoustics, 424-429

6 ）杉本正美, 包清博之, 金炳哲 (1988): 音を配慮し たランドスケープ・スペースのデザインに関する研 究, 造園雑誌 52(5)，259-294

7 ）佐々木実, 他 (1988): 福岡市植物園のサウンドス ケープの現状（福岡市植物園音響導入策定基本計画 のための予備調查), 日本音響学会騒音研究会資料 N88-6-03

8 ）杉本正美, 包清博之, 金炳哲 (1990) : ランドスケー
プ・スペースにおける音導入のための空間領域の設 定に関する研究, 造園雑誌 53(5), 187-192

9 ) 金炳哲, 杉本正美, 包清博之, 藤本一寿, 中村洋 (1991): サウンドスケープと都市空間の係わりに関 する考察, 造園雑誌 54(5), 263-268

10) B.C.Kim, K.Fujimoto, Y.Imamura, H.Nakamura (1991): Acoustical Environment of Residential Area from the View-Point of Soundscape (Part 1), Korea-Japan Joint Symp. on Acoustics, 409-413

11) Y.Imamura, K.Fujimoto, B.C.Kim, H.Nakamura (1991) : Acoustical Environment of Residential Area from the View-Point of Soundscape (Part 2), Korea-Japan Joint Symp. on Acoustics, 414-417

12）金炳哲, 藤本一寿, 今村裕司, 中村洋 (1991): 公 園緑地を基調にした居住環境のアメニティと音, 日 本造園学会関西支部九州研究会研究・事例報告 4

13）R.M.Schafer（訳：鳥越けい子, 他）（1986）:世 界の調律, 平凡社

14）鳥越けい子（1990）: サウンドスケープとはなにか, 環境技術 19(7)，409-411

15）アンケート票には，下記に示す 18 項目を掲げて，そ の中から重要之思われるものを 5 つ以内選択させた。 このとき各項目の選択された率を，ここでは“指摘 率 (\%)" と称している。図ー 3 には指摘率の上位 13位までの項目を掲げた。

ロアンケート票に掲げた項目

- 教育施設の充実, ・交通安全対策の強化, ・自動 車による公害の防止, 一下水道の整備, 一公園や緑 地の整備と充実, ・伝統的町並みの保全, 一歴史的 文化財の保全, ・自然環境の保全, ・海や川の水質 改善,・ウォーターフロントの整備, ・交通網の整 備, ・散乱ごみの対策, ・近隣騒音の防止,・コミュ ニティー活動の充実, ・街路樹などの緑化推進, ・ 防犯対策の強化，・文化施設の充実，・その他（自 由回答）

16）藤本一寿 (1988): 福岡市のサウンドスケープに関 する調査, 日本音響学会関西支部第 4 回音環境談話 会

17）永田泉, 藤本一寿, 松江晃（1990）：音の印象に関 する研究一音の有無による印象の相違一：日本建築 学会中国・九州支部研究報告 第 8号, 157-160 (1991.12.13受付, 1992.8.7.受理) 
Summary : An amenity of residential environment and a regional identity in residential areas are examined from the view-point of soundscape. Nine neighborhood units in Fukuoka City are selected as a study area and people's replies to a questionnaire are statistically analyzed. It is found that the residents think real nature such as open spaces having sounds of bird's or insect's singing is very important for an amenity of residential environment, and identical sounds of residential areas and some physical environmental factors are elements which compose traditional or cultural environment such as historic shrines or temples.

Therefore, it is recognized that the preservation and arrangement of open space in residential area are important for creating amenity and identity of area. 